\title{
Dapatkah Megabentos Epifauna Tumbuh pada Geobag? Studi Kasus di Desa Banyuurip, Gresik
}

\author{
Aida Sartimbul ${ }^{1,2}$, Rafika Devi Agustin ${ }^{1}$, Dhira Khurniawan Saputra ${ }^{1}$, Defri Yona ${ }^{1,2}$, \\ Syarifah Hikmah Julinda Sari ${ }^{1,2}$, Feni Iranawati ${ }^{1,2}$, Nurin Hidayati ${ }^{1,2}$ \\ ${ }^{1}$ Program Studi Ilmu Kelautan Fakultas Perikanan dan Ilmu Kelautan, Universitas Brawijaya, \\ ${ }^{2}$ Marine Resources Exploration and Management (MEXMA) Research Group, \\ Fakultas Perikanan dan Ilmu Kelautan, Universitas Brawijaya, \\ Jl. Veteran, Malang, Jawa Timur 65145 Indonesia \\ Email: aida@ub.ac.id
}

\begin{abstract}
Abstrak
Berbagai upaya telah dilakukan untuk mengatasi masalah abrasi di wilayah pesisir pantai Desa Banyuurip, Gresik. Upaya yang dilakukan salah satunya adalah reboisasi mangrove, namun upaya tersebut belum efektif, sehingga salah satu solusinya adalah dengan dipasangnya geosyntheticbag (geobag), yang merupakan kantong ramah lingkungan berisi pasir yang disusun dan dapat berfungsi sebagai perangkap sedimen dan pelindung pantai. Tujuan dari penelitian ini adalah untuk mengetahui pada bulan ke berapa biota dapat tumbuh pada geosintetik dan struktur komunitas biota yang tumbuh menggunakan metode random transek. Hasil penelitian menunjukkan bahwa megabentos epifauna dapat tumbuh pada geobag pada bulan ke-4 setelah pemasangan, yang terdiri dari 3 spesies yaitu Metopograpsus sp., Ostrea edulis, dan Fistulobalanus albicostatus. Kelimpahan jenis megabentos pada bulan ke-4 rata-rata mencapai 198 individu/ $\mathrm{m}^{2}$, sedangkan kelimpahan pada bulan ke-5 mencapai 259 individu/ $\mathrm{m}^{2}$. Hasil perhitungan indeks struktur komunitas megabentos pada bulan ke-4 dan ke-5 secara berurutan meliputi indeks keanekaragaman (H') bernilai 0,10 dan 0,11; indeks keseragaman (c) bernilai 0,09 dan 0,10; dan indeks dominansi bernilai 0,96 dan 0,96. Berdasarkan penelitian ini, dapat disimpulkan bahwa geobag berfungsi sebagai pencegah abrasi serta sekaligus dapat menyatu dengan media di sekitarnya sehingga diklaim ramah lingkungan, karena dapat ditumbuhi biota yang tidak mengganggu atau merubah struktur komunitas biota di wilayah tersebut.
\end{abstract}

Kata kunci : Megabentos, Geobag, mangrove, transek kuadrat, Desa Banyuurip

Abstract

\section{Can Epifaunal Megabhentos Grow on a Geobag? Case Study in Banyuurip Village, Gresik}

Various attempts have been made to solve the abrasion in the coastal area of Banyuurip Village, Gresik. To overcome this problem, the community planted the mangroves, but these have not been effective. One solution to this problem is to install a geosynthetic bag (geobag), which is an environmentally friendly bag that is arranged and can be function as a sediment trap. The purpose of this study was to determine when the megabenthos can grow in the geosynthetic and how the community structure grow using the quadrant random transect method. The result showed that epifaunal megabenthos could grow on geobag at the fourth month after installation, which consisted of 3 species. The abundance of megabenthos at the $4^{\text {th }}$ month averaged 198 individuals $/ m^{2}$, while the abundance at the $5^{\text {th }}$ month reached 259 individuals $/ \mathrm{m}^{2}$. The structure index ( $H^{\prime}$ ') in January and February were 0.10 and 0.11 , respectively. The similarity index $(C)$ were 0.09 and 0.10, and while the dominance index was 0.96 and 0.96. This study is suggested that the geobag can be function both as a deterrent to abrasion and simultaneously integrate with the surrounding media and be claim as environmentally friendly, because it can be overgrown with biota that does not disturb or change the structure of the biota community in the area.

Keywords : Megabenthos, geobag, mangrove, transect quadrant, Banyuurip Village

\section{PENDAHULUAN}

Desa Banyuurip merupakan salah satu desa di Kecamatan Ujung pangkah, Kabupaten Gresik yang berbatasan dengan Pantai Utara Jawa. Desa ini merupakan salah satu daerah tujuan wisata mangrove yang relatif baru di wilayah Jawa Timur. Terbentuknya wisata mangrove yang dikenal dengan "Banyuurip Mangrove Center (BMC)" 
berawal dari kepedulian Kelompok Nelayan Tirta Buana khususnya Kelompok Pelestari Mangrove dan Lingkungan di Banyu Urip yang diketuai oleh seorang nelayan yang bernama Abdul Mughni. Pada tahun 2013 mereka tergerak untuk melakukan penanaman kembali hutan mangrove di wilayahnya sebagai salah satu upaya untuk melindungi pesisir Desa Banyuurip yang rawan terjadi abrasi (Sartimbul et al., 2019).

Abrasi di wilayah hutan mangrove di Desa Banyuurip ini telah terjadi sejak tahun 2004 yang merupakan dampak dari tingginya aktifitas penebangan hutan mangrove karena alih fungsi lahan tambak (Yona et al., 2017; Sambah et al, 2019; Sartimbul et al., 2019) tanpa adanya upaya reboisasi (Yona et al., 2017). Konversi yang terjadi sebesar 73,92\% dalam kurun waktu 6 tahun (20042010). Abrasi di Banyuurip ini diperparah oleh adanya gelombang tinggi di Laut Jawa (Sambah et al., 2019) terutama di musim Barat (Sartimbul et al., 2019). Hal ini membuktikan betapa pentingnya keberadaan vegetasi mangrove sebagai sebuah sistem perlindungan alami pantai dari gelombang (Puspita dan Karnaningroem, 2014).

Akibat hilangnya hutan mangrove ini, nelayan setempat merasakan perubahan ekosistem dimana organisme-organisme seperti kerang, kepiting dan ikan yang merupakan sumber mata pencaharian mereka menjadi berkurang.

Meskipun usaha reboisasi mangrove di Desa Banyuurip dapat dikatakan berhasil dalam mengembalikan hutan mangrove yang sempat hilang untuk sementara waktu, namun abrasi masih terus terjadi terutama di zona depan (muara) yang berhadapan dengan Laut Jawa dengan gelombang relatif tinggi di musim Barat (Sartimbul et al., 2019) yang menghantam pantai, dan juga gelombang lokal dari aktifitas kapal-kapal nelayan (Mughni, pers. comm.-wawancara). Bibit-bibit mangrove yang baru ditanam sangat mudah terlepas dari substrat sehingga terbawa oleh ombak yang datang, disamping substratnya juga labil (Mughni, pers.comm, wawancara.). Selain itu, abrasi yang terjadi secara terus menerus juga akan mengancam aset desa seperti bangunan yang digunakan sebagai ruang pertemuan warga yang ada di area hutan mangrove.

Oleh karena itu, untuk membantu Kelompok Pelestari Mangrove dan Lingkungan Desa Banyuurip dalam mengatasi masalah abrasi ini, maka salah satu cara yang dilakukan adalah dengan memasang alat pelindung dari gelombang besar sekaligus berfungsi sebagai penjebak sedimen di area belakang pondok pertemuan Desa Banyuurip dengan menggunakan karung geosintetik (geobag) melalui program hibah PKM (Program Kemitraan Masyarakat) pada tahun 2019. Pemasangan geobag ini dapat menciptakan area yang terlindung dari gelombang, terciptanya area baru sehingga bibitbibit mangrove dapat ditanam tanpa khawatir akan terbawa oleh gelombang, serta terciptanya substrat baru bagi tumbuhnya organisme lain di wilayah tersebut (Sartimbul et al., 2019). Pemasangan geobag ini diharapkan dapat menstabilkan substrat area konservasi mangrove Banyuurip dan terjaga ekosistemnya sehingga dapat memberikan manfaat baik bagi nelayan dan masyarakat desa setempat yang menggantungkan hidup pada ekosistem mangrove, juga kepada para pengunjung ekowisata mangrove.

Geosynthetic bag atau biasa disebut dengan geobag merupakan kantung berisi pasir yang disusun menyerupai tembok sehingga dapat menjadi perangkap sedimen (Lawson, 2008). Geobag yang dipasang di Desa Banyuurip berasal dari material polypropylene yang ramah lingkungan dan dalam kurun waktu tertentu akan bersatu dengan substrat alami hingga memungkinkan tumbuhnya biota pada permukaannya (Sartimbul et al., 2019). Sebagai keberlanjutan program, upaya untuk mengetahui keberhasilan PKM, dan monitoring, maka tujuan dari penelitian ini adalah untuk (1) Mengetahui keberhasilan tumbuhnya biota pada geobag, (2) menghitung struktur komunitas megabentos epifauna pada bulan ke-4 dan ke-5 dari awal pemasangan geobag.

\section{MATERI DAN METODE}

Penelitian mengenai struktur komunitas megabentos pada geobag dilakukan di wilayah Kabupaten Gresik, tepatnya di wilayah Banyuurip Mangrove Center Desa Banyuurip, Kecamatan Ujung Pangkah. Lokasi penelitian terletak pada koordinat $112^{\circ} 31^{\prime} 42,096^{\prime \prime} \mathrm{BT}$ dan $6^{\circ} 54^{\prime} 12,852^{\prime \prime}$ LS (Gambar 1).

Pengambilan sampel dilakukan dengan meletakkan 5 transek kuadran berukuran 30 x 30 $\mathrm{cm}$ pada sisi geobag secara random pada bulan Januari (bulan ke-4), lalu ditandai untuk dilakukan pengulangan di bulan Februari (bulan ke-5). Pengambilan sampel ini hanya dapat dilakukan 2 (dua) kali dari 3 (tiga) kali rencana pengambilan sampel (Januari, Februari, dan Maret 2020), dikarenakan kendala penutupan sementara area 
BMC dan pembatasan ketat akses laboratorium di Universitas Brawijaya pada masa pandemi COVID-19. Sebagai pembanding, sampel juga dilakukan pada cerucuk bambu yang berada tepat di sisi titik pengambilan data geobag. Titik pengambilan data dapat dilihat pada Gambar 2. Pengambilan sampel meliputi penghitungan jumlah megabentos serta pengambilan sampel yang diperlukan untuk identifikasi. Jenis megabentos yang diidentifikasi adalah megabentos yang hidup secara epifauna di permukaan geobag.
Pengambilan data parameter air meliputi arus, $\mathrm{pH}$, suhu, dan salinitas. Pengukuran kecepatan arus dilakukan menggunakan alat current meter yang dilakukan saat air pasang pada kedalaman perairan kurang lebih 1 meter. Pengukuran kuat arus pada kedalaman tersebut dikarenakan perairan tidak terlalu dalam, dan diasumsikan sudah mewakili rata-rata kedalaman perairan. Waktu pengambilan data arus adalah pada pukul 12.00 WIB pada bulan Januari dan pukul 11.00 WIB pada bulan Februari saat air mulai pasang.

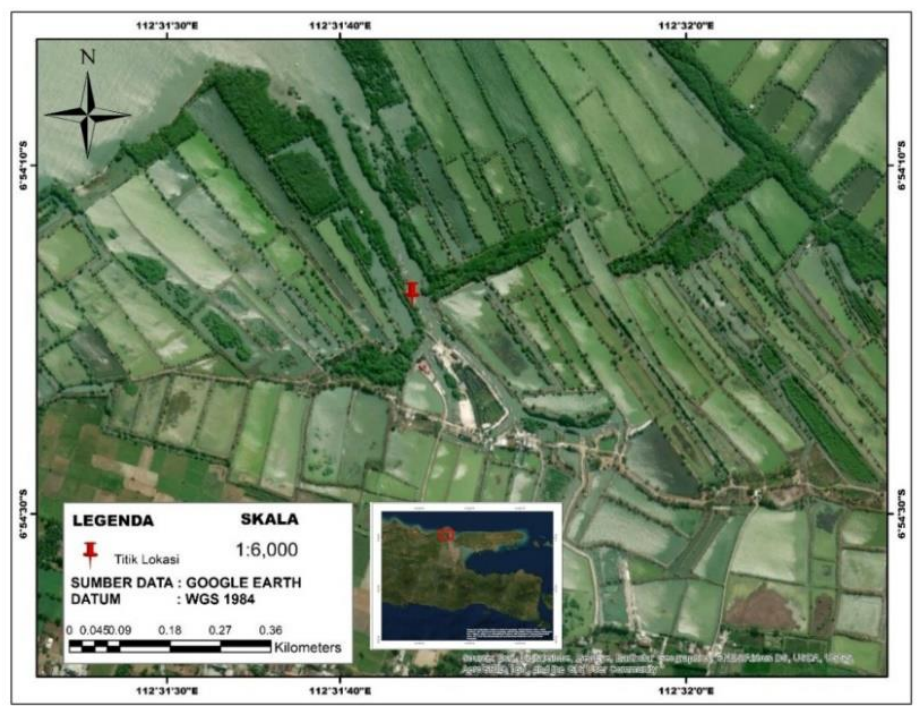

Gambar 1. Peta lokasi penelitian di Banyuurip Mangrove Center (BMC). Pin Merah menunjukkan lokasi pengambilan sampel di daerah pemasangan geobag.

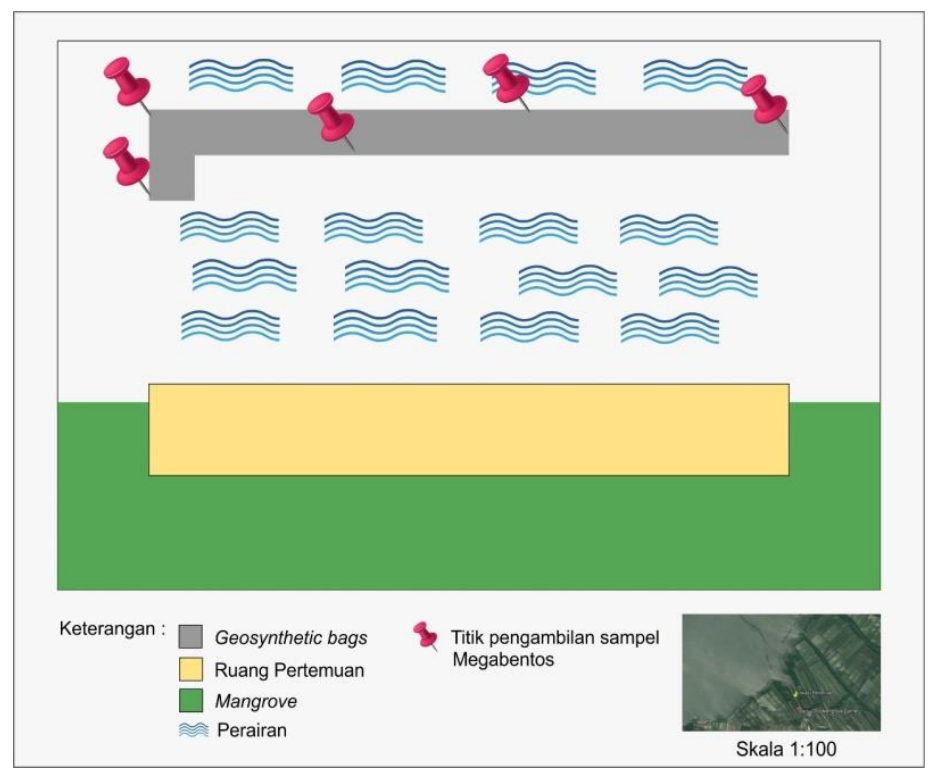

Gambar 2. Titik pengambilan sampel megabentos, yang terdiri dari 5 transek kuadran $30 x 30 \mathrm{~cm}$, dengan masing-masing dilakukan 3 kali ulangan. 
Pengambilan data arus saat kondisi pasang dilakukan karena pada saat tersebut arus secara langsung dapat mempengaruhi keadaan geobag. Saat perairan surut, kondisi geobag tidak terlalu terpengaruh oleh arus karena struktur geobag hanya tenggelam sebagian. Pengambilan data $\mathrm{pH}$ dan suhu menggunakan alat $p H \&$ Temperature tester, cara penggunaannya yaitu dengan memasukkan (menyelupkan) alat ke dalam permukaan perairan selama beberapa saat hingga muncul nilai suhu dan $\mathrm{pH}$. Data yang terbaca pada alat tersebut kemudian dicatat. Sedangkan, pengukuran salinitas menggunakan alat salinometer, dengan cara meneteskan 1 tetes sampel air pada alat, lalu ditunggu beberapa saat hingga muncul nilai salinitas, kemudian data yang terbaca dicatat.

Perhitungan Indeks Struktur Komunitas, Menurut Fitriana (2006), rumus kelimpahan yang dapat digunakan yaitu:

$$
\mathrm{D}_{\mathrm{i}}=\frac{\mathrm{n}}{\mathrm{A}}
$$

Keterangan : $\mathrm{D}=$ Kelimpahan jenis ke-I; $\mathrm{n}=$ Jumlah individu jenis ke-I; $\mathrm{A}=$ Luas kotak pengambilan contoh

Rumus keanekaragaman yang digunakan yaitu rumus indeks keanekaragaman ShannonWeaver (1949), yaitu sebagai berikut:

$$
H^{\prime}=-\sum\left(\frac{n i}{N}\right) \ln \left(\frac{n i}{N}\right)
$$

Keterangan : $\quad \mathrm{H}^{\prime}=$ Indeks keanekaragaman Shannon-Wienner; $\mathrm{Ni}=$ Jumlah individu satu jenis; $\mathrm{N}=$ Jumlah total individu

Pembagian kategori nilai indeks keanekaragaman adalah sebagai berikut: $H^{\prime}<1,0$ : keanekaragaman rendah, miskin, produktifitas sangat rendah sebagai indikasi adanya tekanan yang berat dan ekosistem tidak stabil; 1,0 < H' $<$ 3,322 : keanekaragaman sedang, produktifitas cukup, kondisi ekosistem cukup seimbang, tekanan ekologis sedang; H' > 3,322 : keanekaragaman tinggi, stabilitas ekosistem sangat baik, produktifitas tinggi, tahan terhadap tekanan ekologis

Menurut Pielou (1977), rumus keseragaman dapat menggunakan Indeks Kemerataan (Evenness Index) yaitu:

$$
e=\frac{H^{\prime}}{\ln S}
$$

Keterangan: H' = Indeks keanekaragaman; $\mathrm{S}=$ Jumlah spesies; $e=$ Indeks Keseragaman Evennes

Menurut Insafitri (2010), rumus dominansi suatu spesies dapat diperoleh dari rumus berikut:

$$
C=\sum_{i=1}^{n}\left(\frac{n i}{N}\right)^{2}
$$

Keterangan: $\mathrm{C}=$ Indeks dominansi; $\mathrm{ni}=$ Jumlah individu ke-I; $\mathrm{N}=$ Jumlah total individu

Kisaran kriteria sebagai berikut: $0<\mathrm{C} \leq 0,5=$ tidak ada genus yang mendominasi; $0,5<\mathrm{C}<1=$ terdapat genus yang mendominasi

\section{HASIL DAN PEMBAHASAN}

Penelitian mengenai struktur komunitas megabentos pada geobag ini, dilakukan pengambilan data parameter lingkungan yang dapat mempengaruhi kehidupan biota baik secara langsung ataupun tidak, diantaranya suhu, salinitas, $\mathrm{pH}$, dan kuat arus di sekitar geobag. Data parameter lingkungan pada bulan Januari dan Februari disajikan pada Tabel 1.

Tabel 1. Menunjukkan hasil pengukuran parameter perairan di sekitar geobag cenderung stabil dari bulan Januari hingga Februari. Hasil pengukuran nilai salinitas pada bulan Februari memiliki perbedaan yang signifikan dibandingkan pada bulan Januari, nilai tersebut kurang akurat karena alat yang digunakan mengalami kerusakan.

Nilai suhu pada penelitian yang dilakukan di bulan Januari yaitu $24,33 \pm 1,15^{\circ} \mathrm{C}$ dan bulan Februari $25,00 \pm 0^{\circ} \mathrm{C}$. Suhu yang baik berdasarkan KepMen LH no. 51 Tahun 2004 tentang Baku Mutu Air Laut untuk Biota Laut pada wilayah ekosistem mangrove, yaitu berkisar antara 28,00$32,00^{\circ} \mathrm{C}$ dan oleh karena itu, hasil penelitian menunjukkan bahwa suhu perairan di sekitar geobag kurang sesuai bagi kehidupan biota. Suhu perairan sangat berpengaruh terhadap pertumbuhan dan metabolisme biota, bahkan dalam keadaan tertentu yang tidak sesuai dapat menyebabkan kematian biota (Hamsiah et al., 2016). Nilai pH pada bulan Januari dan Februari yaitu 7,70 yang berarti angka tersebut tergolong stabil dan sesuai untuk kehidupan biota berdasarkan Keputusan Menteri Lingkungan Hidup no. 51 Tahun 2004 tentang Baku Mutu Air Laut. Nilai $\mathrm{pH}$ menurut baku mutu tersebut yang sesuai untuk biota yaitu berkisar antara 7,00-8,50. 
Salinitas pada lokasi penelitian yaitu bernilai $25 \%$ pada bulan Januari dan $11 \%$ pada bulan Februari karena alat yang digunakan mengalami kerusakan. Oleh karena data salinitas pada saat penelitian di bulan Februari tidak valid, maka dilakukan analisis berdasarkan data-data pendukung lainnya yang dapat mempengaruhi salinitas di perairan sekitar pemasangan geobag. Berdasarkan data pasang surut air laut yang diperoleh dari Badan Informasi Geospasial (BIG) pada bulan Februari tepat saat pengambilan data yaitu 25 Februari pukul 11:00 WIB, kondisi perairan pasang dengan nilai $2,10 \mathrm{~m}$ dan tinggi permukaan air 0,14 m (BIG, 2020). Kondisi perairan yang mengalami pasang mengakibatkan massa air laut masuk ke sungai dan salinitas cenderung meningkat (Purnaini dan Purwono, 2018). Curah hujan di Kabupaten Gresik pada beberapa hari sebelum pengambilan data yaitu pada 23 Februari sebesar 46,60 mm (intensitas sedang); 24 Februari sebesar 7,40 mm (rendah); 25 Februari sebesar 2,80 mm (rendah) (BMKG, 2020), yang berarti tingkat salinitas di perairan sekitar pemasangan geobag seharusnya bernilai normal yaitu bekisar antara 18-25\% (Saleh, 2014; Madyowati dan Khusyairi, 2020).

Arus yang ada di lokasi penelitian yaitu sebesar $0,20 \mathrm{~m} /$ detik pada bulan Januari dan 0,22 $\mathrm{m} /$ detik pada bulan Februari. Nilai arus tersebut tergolong arus lambat (Mason, 1981). Arus yang lambat dapat memudahkan biota untuk menempel pada geobag. Alpiana et al. (2019) menjelaskan bahwa semakin tinggi kecepatan arus perairan maka akan memperkecil peluang terjadinya penempelan biota pada suatu substrat, namun sebaliknya, semakin besar kecepatan arus maka akan memperbesar kemungkinan penempelan.

\section{Identifikasi Jenis Megabentos}

Ekosistem mangrove memiliki keanekaragaman hayati yang cukup tinggi, berbagai jenis biota hidup di ekosistem mangrove, salah satunya adalah dari kelompok moluska (Hutama et al., 2019). Proses identifikasi jenis megabentos pada penelitian ini menggunakan acuan pada web identifikasi http://www.wild singapore.com, http://www.marinespecies.org, dan beberapa jurnal terkait. Hasil identifikasi jenis megabentos disajikan pada Tabel 2.

Metopograpsus sp. atau biasa disebut dengan kepiting ungu pemanjat (Purple Climber $\mathrm{Crab}$ ) merupakan jenis kepiting bakau yang hidup pada perakaran pohon mangrove. Kepiting ini memanjat untuk menghindari air pasang dan predator. Metopograpsus sp. memakan beberapa jenis alga, serasah daun mangrove, sedimen organik, bakteri, serta kepiting jenis Mictyris brevidactylus (Poon et al., 2010). Metopograpsus $s p$. sendiri biasanya ditemukan pada ekosistem mangrove jenis Rhizophora apiculata (Aunurohim et al., 2015). Pernyataan tersebut sesuai dengan kondisi geobag yang berada pada ekosistem mangrove berjenis Avicennia sp. dan Rhizophora sp. sehingga memungkinkan adanya Metopograpsus sp. pada wilayah dekat geobag. Kepiting ini tinggal untuk mencari makanan berupa alga pada geobag. Kepiting ini akan memanjat cerucuk bambu untuk menghindari perairan yang pasang. Pengambilan data pada penelitian ini dilakukan saat perairan surut sehingga Metopograpsus sp. belum memanjat pada bambu.

Ostrea edulis atau biasa disebut dengan tiram datar berasal dari perairan Eropa dan mengalami translokasi hingga hampir ke seluruh perairan dunia. Tiram ini dapat berkembang di berbagai perairan dengan suhu sekitar $15^{\circ} \mathrm{C}$ atau lebih (Bromley et al., 2016). O. edulis merupakan jenis biota sesil dan bersifat filter-feeder (Lallias et al., 2010). Habitat Osetrea edulis adalah di daerah estuari yang berair payau atau air laut, menempel pada substrat keras (batu), pasir berlumpur, lumpur dengan dasar yang keras, serta lumpur dengan kerikil dan tanah liat yang mengeras dengan kedalaman 0-80 m (Perry et al., 2019).

Tabel 1. Parameter kualitas perairan

\begin{tabular}{cccc}
\hline Parameter & Januari & Februari & $\begin{array}{c}\text { Baku Mutu Air Laut untuk } \\
\text { Biota Mangrove* }\end{array}$ \\
\hline Suhu $\left({ }^{\circ} \mathrm{C}\right)$ & $24,33 \pm 1,15$ & $25,00 \pm 0,00$ & $28-32$ \\
pH & $7,70 \pm 0,10$ & $7,70 \pm 0,10$ & $7-8,5$ \\
Salinitas (\%) & $25,00 \pm 0,71$ & $11,00 \pm 2,30$ & $\mathrm{~s} / \mathrm{d} 34$ \\
Arus (m/detik) & $0,20 \pm 0,00$ & $0,22 \pm 0,03$ & - \\
\hline
\end{tabular}

Keterangan: *KepMen LH No. 51 Tahun 2004 Tentang Baku Mutu Air Laut 
Tabel 2. Hasil identifikasi megabentos

\begin{tabular}{llll}
\hline \multicolumn{1}{c}{ Jenis biota } & Sifat hidup & Ukuran & Dokumentasi \\
Lapang
\end{tabular}

Ostrea edulis lebih menyukai substrat berbahan besi dan beton daripada substrat paralon dan karet. Penelitian pada geobag, jenis substrat geobag yang berbahan dasar menyerupai paralon bisa jadi merupakan faktor yang menyebabkan kelimpahan $O$. edulis tidak begitu banyak. Ostrea edulis sendiri dapat hidup menempel pada geobag karena geobag memenuhi syarat tempat tinggalnya, yaitu berupa substrat keras dan berada di daerah estuari. Suhu perairan di sekitar geobag juga memenuhi syarat untuk $O$. edulis untuk dapat bereproduksi. Arus di sekitar geobag pun cenderung lambat sehingga memudahkannya untuk menempel.

Fistulobalanus albicostatus merupakan jenis teritip yang hidup pada ekosistem mangrove dan menempel pada batang serta daun mangrove (Chan dan Leung, 2007), bebatuan dan cangkang moluska . Penelitian yang pernah dilakukan oleh Li dan Chan (2008), F. albicostatus dapat hidup menempel pada batang dan daun mangrove. Sedangkan pada penelitian ini, diketahui bahwa $F$. albicostatus juga dapat hidup menempel pada permukaan geobag. Teritip jenis ini dapat tumbuh pada permukaan geobag karena geobag dipasang dekat dengan ekosistem mangrove. Penempelan biota ini lebih banyak ditemukan pada bambu daripada geobag karena bambu memiliki nutrien alami untuk tumbuhnya biofilm, sehingga penempelan pada geobag membutuhkan waktu lebih lama.

F. albicostatus yang menempel pada geobag dan bambu berada pada fase dewasa dengan ukuran yang beragam. F. albicostatus memiliki cangkang keras berwarna putih dan terkadang terdapat garis ungu atau abu-abu (Tøttrup et al., 2010). Penelitian ini menunjukkan bahwa kelimpahan $F$. albicostatus masih terbilang sedikit dan rata-rata ukurannya belum terlalu besar karena proses pembentukan lapisan biofilm pada geobag terbentuk relatif lama. Penempelan teritip yang terjadi dapat menyebabkan peningkatan adanya makoralga, serta dapat membantu meningkatkan kejernihan air serta mempengaruhi kandungan fosfor dalam perairan (Affandy et al., 2019).

\section{Struktur Komunitas Megabentos}

Setelah melakukan perhitungan jumlah megabentos pada lokasi penelitian, hasil perhitungan kelimpahan megabentos pada geobag disajikan pada Tabel 3. Berdasarkan Tabel 4 diatas, kelimpahan megabentos pada geobag didominasi 
oleh jenis Fistulobalanus albicostatus, begitu pula dengan cerucuk bambu. Jika dibandingkan secara kuantitatif (jumlah kelimpahan), kelimpahan megabentos lebih banyak ditemukan pada permukaan bambu daripada geobag.

Tabel 5 menunjukkan indeks keanekaragaman megabentos pada geobag di bulan Januari yaitu 0,10 dan bertambah menjadi 0,11 pada bulan Februari. Meskipun mengalami perkembangan, nilai indeks keanekaragaman menunjukkan bahwa keanekaragaman megabentos pada geobag di bulan Januari dan Februari tergolong rendah, miskin, produktifitas rendah. Indeks keanekaragaman megabentos pada cerucuk bambu bernilai 0 di bulan Januari dan Februari. Nilai indeks tersebut menunjukkan bahwa indeks keanekaragaman megabentos pada bambu di bulan Januari dan Februari tergolong rendah, miskin, produktifitas rendah. Nilai indeks keseragaman pada geobag bulan Januari yaitu 0,09 dan bulan Februari 0,10. Nilai tersebut menunjukkan keseragaman populasi kecil. Indeks keseragaman pada bambu bernilai 0 di bulan Januari dan Februari, sehingga menunjukkan bahwa keseragaman kecil. Nilai indeks dominansi megabentos pada geobag di bulan Januari dan Februari adalah 0,96, yang menunjukkan adanya spesies yang mendominasi. Indeks dominansi pada bambu di bulan Januari dan Februari bernilai 1, atau dapat dikatakan terdapat spesies yang mendominasi. Spesies yang mendominasi pada permukaan geobag dan bambu adalah Fistulobalanus albicostatus.

Penelitian ini menunjukkan bahwa indeks keanekaragaman megabentos pada geobag tergolong rendah, indeks keseragaman populasi kecil, dan terdapat spesies yang mendominasi. Alasan yang menyebabkan keanekaragaman organisme pada daerah estuari tergolong rendah yaitu tidak semua organisme memiliki kemampuan yang baik dalam beradaptasi dengan lingkungan estuari yang berfluktuatif.

Tabel 3. Kelimpahan megabentos pada geobag

\begin{tabular}{clcc}
\hline \multirow{2}{*}{ No. Spesies } & \multicolumn{2}{c}{ Kelimpahan Jenis (Ind/m) } \\
\cline { 3 - 4 } & & Januari & Februari \\
\hline 1 & Metopograpsus sp. & $9 \pm 10$ & $13 \pm 30$ \\
2 & Ostrea edulis & $2 \pm 00$ & $2 \pm 00$ \\
3 & Fistulobalanus albicostatus & $582 \pm 48$ & $762 \pm 47$ \\
& Rata-rata & $198 \pm 33$ & $259 \pm 44$ \\
\hline
\end{tabular}

Tabel 4. Kelimpahan megabentos pada bamboo

\begin{tabular}{|c|c|c|c|}
\hline \multirow{2}{*}{ No } & \multirow{2}{*}{ Spesies } & \multicolumn{2}{|c|}{ Kelimpahan Jenis (Ind/m) } \\
\hline & & Januari & Februari \\
\hline 1 & Metopograpsus sp. & 0 & 0 \\
\hline 2 & Ostrea edulis & 0 & $4 \pm 1$ \\
\hline 3 & Fistulobalanus albicostatus & $653 \pm 10$ & $951 \pm 29$ \\
\hline & Rata-rata & $218 \pm 377$ & $319 \pm 548$ \\
\hline
\end{tabular}

Tabel 5. Indeks keanekaragaman, keseragaman, dan dominansi

\begin{tabular}{cccccccc}
\hline \multirow{2}{*}{ No. } & \multirow{2}{*}{ Bulan } & \multicolumn{2}{c}{$\mathrm{H}^{\prime}$} & \multicolumn{2}{c}{$\mathrm{E}$} & \multicolumn{2}{c}{$\mathrm{C}$} \\
\cline { 3 - 8 } & & Geobag & Bambu & Geobag & Bambu & Geobag & Bambu \\
\hline 1 & Januari & 0,10 & 0 & 0,09 & 0 & 0,96 & 1 \\
2 & Februari & 0,11 & 0 & 0,10 & 0 & 0,96 & 1 \\
\hline
\end{tabular}


Pemasangan geobag pada penelitian ini dilakukan pada daerah estuari tepatnya di wilayah ekosistem mangrove. Organisme megabentos yang ditemukan pada ekosistem mangrove di sekitar geobag antara lain Cassidula aurisfelis, Telescopium telescopium, Fistulobalanus albicostatus, Metopograpsus sp., dan Bolinus brandaris. Megabentos yang tumbuh pada geobag terdiri dari Metopograpsus sp., Ostrea edulis, serta Fistulobalanus albicostatus. Ketiga jenis megabentos yang ditemukan tersebut merupakan jenis organisme yang hidup pada ekosistem mangrove tempat pemasangan geobag, serta menunjukkan bahwa tidak semua organisme yang ditemukan pada mangrove dapat ditemukan juga pada geobag. Faktor yang dapat mempengaruhi mengapa tidak semua organisme yang ditemukan pada ekosistem mangrove dapat hidup juga pada geobag adalah perbedaan jenis substrat, tingkat kekasaran permukaan substrat, serta intensitas genangan air. Penempelan organisme lebih mudah terjadi pada substrat bertekstur padat dengan permukaan cenderung kasar dan warna gelap (Marhaeni, 2012). Permukaan geobag yang terbuat dari polypropylene cenderung lebih halus daripada permukaan batang dan akar mangrove sehingga penempelan organisme lebih sulit terjadi.

Proses adanya penempelan organisme pada geobag membutuhkan waktu yang sedikit lebih lama karena permukaannya yang cenderung halus serta nutrien alami yang minim. Penempelan dan pertumbuhan biofilm hingga adanya megabentos memakan waktu kurang lebih 3-4 bulan dari waktu pemasangan geobag. Kemungkinan adanya spesies-spesies baru yang akan menempel pada geobag bisa saja terjadi dalam beberapa waktu ke depan. Faktor-faktor yang dapat memungkinkan adanya pertumbuhan organisme lain pada geobag adalah kondisi lingkungan di sekitar geobag yang sangat kaya akan nutrien karena berada pada ekosistem mangrove. Kondisi arus perairan pun sangat sesuai karena cenderung lambat sehingga memudahkan organisme untuk dapat menempel pada permukaan geobag. Suhu perairan stabil sehingga memudahkan organisme untuk beradaptasi. Salinitas perairan yang tidak stabil menjadi salah satu faktor yang dapat menghambat pertumbuhan karena banyak terpengaruh oleh perairan laut dan daratan. Jenis organisme yang mungkin dapat tumbuh pada geobag adalah jenis bivalvia dan gastropoda.

Penempelan biota pada suatu substrat disebut dengan biofouling. Biofouling terjadi dengan tahapan: mikroorganisme berkoloni dan menempel di permukaan substrat, nutrien pada air akan dimanfaatkan oleh mikroorganisme untuk proses metabolisme dan berkembang biak. Perkembangan mikroorganisme ini akan memacu penempelan markoorganisme. Jenis organisme yang menempel saat terjadi macrofouling antara lain teritip, tiram, kerang, dan sebagainya. Organisme yang menempel bergantung pada interaksi lingkungan dan bahan substrat sehingga jenis biofouling dapat berbeda-beda di setiap tempat. Jenis spesies organisme sendiri tergantung pada susunan biofilm. Variabel lain yang mempengaruhi yaitu lokasi, kedalaman, iklim, suhu, serta kandungan oksigen (Takahashi, 2020). Penempelan organisme megabentos pada geobag relatif lebih sedikit jika dibandingkan dengan penempelan pada objek lain yang dijadikan perbandingan seperti cerucuk bambu.

Membran polypropylene memiliki karakteristik hidrofobik, sehingga memiliki potensi besar untuk terjadinya fouling jika dibandingkan dengan membran yang bersifat hidrofilik (Taghaddosi et al., 2017). Kondisi geobag yang tidak sepenuhnya tenggelam saat perairan pasang menyebabkan penempelan biofilm yang lebih sedikit. Penempelan biofilm akan lebih mudah terjadi saat suatu permukaan tidak banyak berinteraksi dengan udara terbuka dan banyak masukan oksigen (Etemadi et al., 2020). Kesimpulan efek penggunaan geobag berbahan polypropylene yang bersifat hidrofobik yaitu cenderung negatif karena akan membuat geobag tidak tahan lama. Geobag berbahan polypropylene dapat lebih kuat jika diberi tambahan lapisan nanoclay karena akan mengurangi terjadinya biofouling (Taghaddosi et al., 2017).

\section{KESIMPULAN}

Penelitian ini menunjukkan bahwa megabentos epifauna dapat tumbuh pada media geobag setelah 4 (empat) bulan pemasangan di wilayah estuari Desa Banyuurip, Ujung Pangkah, Gresik. Adapun biota yang tumbuh meliputi Metopograpsus sp. (purple climber crab), Ostrea edulis (tiram datar), dan Fistulobalanus albicostatus (teritip mangrove). Kelimpahan Metopograpsus sp. sebanyak 9 individu $/ \mathrm{m}^{2}$, Ostrea edulis sebanyak 2 individu/ $\mathrm{m}^{2}$, dan Fistulobalanus albicostatus sebanyak 582 individu $/ \mathrm{m}^{2}$ pada bulan Januari (ke-4). Kelimpahan Metopograpsus $s p$. sebanyak 13 individu $/ \mathrm{m}^{2}$, Ostrea edulis sebanyak 2 individu $/ \mathrm{m}^{2}$, dan Fistulobalanus albicostatus 
sebanyak 762 individu $/ \mathrm{m}^{2}$ pada bulan Februari (ke5). Indeks keanekaragaman (H') megabentos bernilai 0,10; keseragaman (c) bernilai 0,09; dan dominansi bernilai 0,96 pada bulan Januari (ke-4). Indeks keanekaragaman bernilai ( $\left.H^{\prime}\right)$ 0,11, keseragaman (c) bernilai 0,10 , dan dominansi bernilai 0,96 pada bulan Februari (ke-5). Penelitian ini diharapkan dapat digunakan sebagai salah satu acuan dalam upaya pencegahan abrasi yang cukup ramah lingkungan dengan pemasangan geobag. Penelitian selanjutnya disarankan dapat membandingkan pertumbuhan megabentos pada geobag dan substrat lain yang berada di sekitar lokasi penelitian, sehingga dapat diketahui laju pertumbuhan megabentos pada berbagai media baik alami maupun buatan, serta efektifitas macam-macam media sebagai pencegah abrasi yang ramah lingkungan.

\section{UCAPAN TERIMA KASIH}

Ucapan terima kasih disampaikan kepada Pak Abdul Mugni (pelopor penggerak penanaman mangrove di Desa Banyu Urip), para nelayan dan sukarelawan BMC, serta Kepala Desa Banyu Urip atas kerjasama dan dukungannya pada kegiatan ini. Terima kasih juga ditujukan pada Fakultas Perikanan dan Ilmu Kelautan, Universitas Brawijaya atas dukungan fasilitas laboratorium. PKM ini didanai dari KEMENRISTEK-DIKTI No. 050/SP2H/PPM/DPRM/2019.

\section{DAFTAR PUSTAKA}

Affandy, M.A.M., Madin, J., Jakobsen, K.P. \& Auluck, M., 2019. Macrofouling Development on Artificial Structure at Karambunai Bay, Sabah Malaysia. Jurnal of Physics: Conference Series, 1358.

Alpiana, N., Cndri, D.A., Ghazali, M. \& Ahyadi, H., 2019. Komparasi Jenis dan Laju Pertumbuhan Moluska yang Menempel pada Berbagai Media Sintetik di Tiga Ekosistem Pesisir Sekotong. Biowal, 5(1):12-17.

Aunurohim, Sujatmiko, B.K., Ikrom, A.B., Kuswytasari, N.D., Shovitri, M., Zulaika, E., Alami, N.H., Saputro, T.B., Muslihatin, W., Ermavitalini, D., \& Ersan, T., 2015. Benthic Macrofauna in Mangrove Zonation at Poteran Island, Madura, Indonesia. Journal Application Environment Biology Science, 5(5): 90-95.

BIG. 2020. Tide Prediction. http://tides.big.go.id /pasut/. Diakses pada 26 Juni 2020.
BMKG. 2020. Laporan Iklim Harian Januari 2020. http://dataonline.bmkg.go.id. Diakses pada 25 Juni 2020.

BMKG. 2020. Laporan Iklim Harian Februari 2020. http://dataonline.bmkg.go.id. Diakses pada 25 Juni 2020.

Bromley, C., McGonigle, C., Ashton, E.C., \& Roberts, D., 2016. Bad Moves: Pros and Cons of Moving Oysters - A Case Study of Global Translocations of Ostrea edulis linnaeus, 1758 (Mollusca: Bivalvia). Ocean \& Coastal Management Journal. 122:103-115.

Chan, B.K.K. \& Leung, P.T.Y., 2007. Antennular Morphology of the Cypris Larvae of the Mangrove Barnacle Fistulobalanus albicostatus (Cirripedia: Thoracica: Balanomorpha). Journal of the Marine Biological Association, 87(4): 913-915.

Etemadi, H., Fonouni, M. \& Yegani, R., 2020. Investigation of Antifouling Properties of Polypropylene/Tio2 Nanocomposite Membrane Under Different Aeration Rate in Membrane Bioreactor System. Biotechnology Reports, 25:p.e00414

Fitriana, Y.R., 2006. Keanekaragaman dan Kemelimpahan Makrozoobentos di Hutan Mangrove Hasil Rehabilitasi Taman Hutan Raya Ngurah Rai Bali. Biodiversitas, 7(1): 6772.

Hamsiah, Mahmudi, M., Herawati, E.Y., \& Sartimbul, A., 2016. Seasonal Variation of Bivalve Diversity in Seagrass Ecosystem of Labakkang Coastal Water, Pangkep, South Sulawesi, Indonesia. AACL Bioflux, 9(4): 775784

Hutama, H.F.R., Hartati, R., \& Djunaedi, A., 2019. Makrozoobenthos Gastropoda pada Vegetasi Mangrove di Pesisir Utara, Semarang. Buletin Oseanografi Marina, 8(1):37-43.

Insafitri, 2010, Keanekaragaman, Keseragaman, dan Dominansi Bivalvia di Area Lumpur Lapindo Muara Sungai Porong. Jurnal Kelautan, 3(1):54-59

Lallias, D., Boudry, P., Lapègue, S., King, J.W., Beaumont, A.R., 2010. Strategies for the retention of high genetic variability in European flat oyster (Ostrea edulis) restoration programmes. Conservation Genetics, 11(5): 1899-1910.

Lawson, C.R., 2008. Geotextile Containment for Hydraulic and Environmental Engineering. Geosynthetics International, 15(6): 384-427. 
Li, S.W., \& Chan, B.K.K., 2008. Adaptations to Barnacle Fouling in the Mangroves Kandelia obovata and Aegiceras corniculatum. Marine Biology, 155(3): 263-271.

Madyowati, S.O., \& Khusyairi, A., 2020. Keanekaragaman Komunitas Makrobenthos pada Ekosistem Mangrove di Desa Banyuurip Kecamatan Ujung Pangkah Kabupaten Gresik. Journal of Fisheries and Marine Science, 4(1):116-124.

Marhaeni, B., 2012. Biofouling Pada Beberapa Jenis Substrat Permukaan Kasar Dan Halus. Jurnal Sains Akuatik, 14(1):41-47.

Mason, C.F, 1981, Biology of Freshwater Pollutio, Longman Group Limited, London.

Perry, Frances., Angus Jackson., and Samantha Garrard. 2019. Native oyster (Ostrea edulis). The Marine Life Information Network. The Marine Biological Association. Diakses pada 30 November 2020, dari www.marlin.ac.uk.

Pielou, E.C. 1977. Mathematical Ecology. Wiley, New York.

Poon, D.Y.N., Chan, B.K.K. \& Williams, G.A., 2010. Spatial and Temporal Variation in Diets of the Crabs Metopograpsus frontalis (Grapsidae) and Perisesarma bidens (Sesarmidae): Implications for Mangrove Food Webs. Hydrobiologia, 638(1):29-40.

Purnaini, R., \& Purwono, S., 2018. Pengaruh Pasang Surut Terhadap Sebaran Salinitas di Sungai Kapuas Kecil. Jurnal Teknologi Lingkungan Lahan Basah, 01(2): 021-029.

Puspita, C., \& Nieke, K. 2014. Model Hubungan Karakteristik Vegetasi Mangrove Terhadap Atenuasi Gelombang (Studi Kasus di Wilayah Pantai Ujung Pangkah). Prosiding Seminar Nasional Manajemen Teknologi XXII Program Studi MMT-ITS Surabaya, 24 Januari 2014.

Saleh, B.A., 2014. Studi Kandungan Logam Berat Merkuri (Hg) dan Prediksi Kandungan Metil Merkuri $(\mathrm{CH} 3 \mathrm{Hg})$ pada Organ Kerang Darah (Anadara granosa) di Kecamatan Sidayu dan Kecamatan Banyuurip, Pantai Utara Gresik, Jawa Timur. Jurnal Ilmiah Perikanan dan
Kelautan 6(2):207-213, doi: 10.20473/jipk. v6i2.11310

Sambah, A.B., Defri Y., Nurin H. \& Didied P.A. 2019. Sosialisasi Pengemasan dan Pemasaran Produk Olahan Mangrove pada Kelompok Sadar Wisata (POKDARWIS) Desa Banyuurip, Ujung Pangkah, Gresik. Prosiding Seminar Nasional Perikanan dan Kelautan VIII ISBN : 978-602-72784-3-1. Universitas Brawijaya.

Sartimbul, A., Defri Y., Syarifah H.J.S., M. Arif Z.F., \& M. Arief R. 2019. Aplikasi Karung Geosintetik Untuk Pengendalian Abrasi di Wilayah Konservasi Mangrove Banyuurip Kabupaten Gresik. Prosiding Seminar Nasional Perikanan dan Kelautan ISBN : 978602-72784-3-1. Universitas Brawijaya.

Shannon, C.E., \& Weaver, W. 1949. The Mathematical Theory of Communication. University of Illinois Press, Urbana, Illinois.

Taghaddosi, S., Akbari, A. \& Yegani, R., 2017. Preparation, Characterization and AntiFouling Properties of Nanoclays Embedded Polypropylene Mixed Matrix Membranes. Chemical Engineering Research and Design, 125:35-45.

Takahashi, T., 2020, Monitoring Artificial Materials and Microbes in Marine Ecosystems: Interactions and Assessment Methods, Bentham Science Publishers, Singapore.

Tøttrup, A.P., Chan, B.K.K., Koskinen, H., \& Høeg, J.T., 2010. 'Flying Barnacles': Implications for the Spread of NonIndigenous Species. Biofouling, 26: 577-582.

Wildsingapore. 2020. Metopograpsus sp. www.wildsingapore.com. Diakses pada 27 Juni 2020

Yona, D., Nurin, H., Syarifah, H.J.S., Irfan N.A., \& Kharisma W.S., 2017. Teknik Pembibitan dan Penanaman Mangrove di Banyuurip Mangrove Center, Desa Banyuurip, Kecamatan Ujung Pangkah, Kabupaten Gresik. Jurnal Pengabdian Masyarakat JDinamika, 3(1):67-70. doi: 10.25047/j-dina mika.v3i1.744 